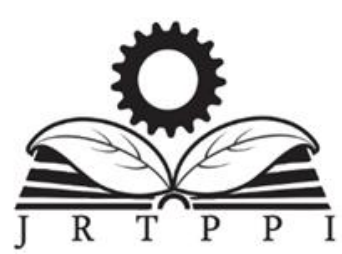

Vol. 12 No. 2 (2021) 15-24

Jurnal Riset

Teknologi Pencegahan Pencemaran Industri

Kementerian

Perindustrian

REPUBLIK INDONESIA

Journal homepage : http://www.jrtppi.id

\title{
Air Pollution Dispersion Modelling using GRAL in Area Near Coal-Steam Power Plant at Central Java
}

\author{
Januar Arif Fatkhurrahman ${ }^{1 *}$, Ikha Rasti Julia Sari ${ }^{1}$, Yose Andriani ${ }^{1}$ \\ ${ }^{1}$ Balai BesarTeknologi Pencegahan Pencemaran Industri, Jalan Ki Mangunsarkoro No. 6 Semarang
}

\begin{tabular}{l} 
A R T IC L E I N F O \\
\hline Article history: \\
Received 20 May 2021 \\
Received in revised form 29 September \\
2021 \\
Accepted 04 October 2021 \\
Available online 10 December 2021 \\
\hline Keywords: \\
GRAL \\
Dispersion \\
Sulfur dioxide \\
Nitrogen dioxide \\
Air quality model
\end{tabular}

\begin{abstract}
A B S T R A C T
Sulfur dioxide and Nitrogen dioxide were significant emissions emitted from coal-steam power plants that may cause health problems for humans and damage the environment. Studying the $\mathrm{SO}_{2}$ and $\mathrm{NO}_{2}$ gradients in Indonesian residential communities is critical for evaluating resident's $\mathrm{SO}_{2}$ and $\mathrm{NO}_{2}$ exposure. The method developed to assist analysis of spatial $\mathrm{SO}_{2}$ and $\mathrm{NO}_{2}$ gradients on a community scale combines a mesoscale Lagrangian dispersion model with field observations around coal-steam power plants using GRAL. The objectives of this study focused on GRAL dispersion of $\mathrm{SO}_{2}$ and $\mathrm{NO}_{2}$ in an Indonesian residential community near the coal-steam power plant, with a $6 \mathrm{~km} \times 8 \mathrm{~km}$ resolution. Analysis of this model indicates a correlation between simulation and observation, with $\mathrm{SO}_{2}$ coefficient correlation (R) within $0.5-0.82$ and $\mathrm{NO}_{2}$ coefficient correlation $(\mathrm{R})$ within $0.30-0.59$. Model performances analyze by NMSE and FB. The $\mathrm{SO}_{2}$ model is comparable to observation data since it has a better average NMSE and FB than the $\mathrm{NO}_{2}$ model. Due to data limitation of observation collected by grab sampling instead of continuous ambient measurement system affect different respond time compared with hourly data from the model.
\end{abstract}

\section{INTRODUCTION}

Sulfur Oxides, mainly Sulfur Dioxide $\left(\mathrm{SO}_{2}\right)$, emitted by coal-steam power plants may cause health impacts for humans with increased cardiovascular disease risk in long term exposures (Fatkhurrahman et al., 2020; Lin et al., 2018). Short-term exposures can make breathing difficult for people with asthma (Galán, Tobías, Banegas, \& Aránguez, 2003). It also degrades the climate by producing acid rain in the environment (Jain, Cui, \& Domen, 2016). The coal-steam power plant also releases massive Nitrogen Oxide as Nitrogen Dioxide $\left(\mathrm{NO}_{2}\right)$ into the atmosphere; the photochemical reaction may produce atmospheric ozone, which is harmful for lung function and other respiratory problems (Zhang, Wei, \& Fang, 2019). In Indonesia, twenty coal-steam power plants utilize electricity generation, primarily built in Java, close together to dense housing.

In comparison, more than ten coal-steam power plants are planned for construction in future years (Quina, Fadhillah, Jiaqiao, \& Zhao, 2017). Mainly, coal-steam power plants conduct emission tests using external testing laboratories; they could also install a continuous emission monitoring system (Simbolon et al., 2021). Therefore, studying the $\mathrm{SO}_{2}$ and $\mathrm{NO}_{2}$ gradients in Indonesian residential communities is critical for evaluating resident's $\mathrm{SO}_{2}$ and $\mathrm{NO}_{2}$ exposure. In Indonesia, there are several problems to conduct a comprehensive analysis of $\mathrm{SO}_{2}$ and $\mathrm{NO}_{2}$ exposure in the environment. The complexity of the emissions and building arrangements spreads in large areas.

\footnotetext{
*Correspondence author.

E-mail : januarfa@gmail.com (Januar Arif Fatkhurrahman)

doi : https://10.21771/jrtppi.2021.v12.no.2.p15-24

2503-5010/2087-0965@ 2021 Jurnal Riset Teknologi Pencegahan Pencemaran Industri-BBTPPI (JRTPPI-BBTPPI).

This is an open acces article under the CC BY-NC-SA license (https://creativecommons.org/licenses/by-nc-sa/4.0/).

Accreditation number : (LIPI) 756/Akred/P2MI-LIPI/08/2016
} 
The lack of meteorological data available for the public makes the air pollution study take a difficult step.

Indonesian coal-steam power plants commonly built near the coast may cause air pollution dispersion through the coastal climate into the residents near the beach. It will be affected dominantly by sea windblown into the land, dispersing $\mathrm{SO}_{2}$ and $\mathrm{NO}_{2}$ from coal-steam power plants chimney for the entire year. As two significant seasons in Indonesia, the rainy and dry seasons, more pollution in the dry season will be possible than in the rainy season. The method was developed to assist in analyzing spatial $\mathrm{SO}_{2}$ and $\mathrm{NO}_{2}$ gradients on a community scale that combines a mesoscale Lagrangian dispersion model with field observations around coal-steam power plants. Popular air quality models like WRF-Chem and AERMOD can be utilized on regional to urban scales (Grell et al., 2005; Mijling, 2020). AERMOD is a paid software with more than USD 1000 cost to buy, while WRF-Chem is free software but needs advanced programming language knowledge. This study employs the Graz Lagrangian (GRAL) model for $\mathrm{SO}_{2}$ and $\mathrm{NO}_{2}$ simulation (Oettl, 2014; Romanov, 2020). GRAL can be applied for gaseous and particulates simulation and prediction for flat and complex terrain, mainly based on daily, monthly, and annual means (Anfossi et al., 2006). This GRAL system is entirely free, and study using GRAL seems to be applied both for urban scale, areas near industries, and even some tight tunnel openings (Ling, Candice Lung, \& Uhrner, 2020). GRAL system is commonly prevalent in Europe, based on published validation studies by annual means (Kurz et al., 2014). There is also a GRAL limitation on chemical reaction modeling in the atmosphere that should be noticed when air dispersion simulation conduct in the area with chemical reaction happened. However, GRAL has not yet been validated in an Asian residential community, especially for Indonesian typical residential and population arrangement. In this study, $\mathrm{SO}_{2}$ and $\mathrm{NO}_{2}$ monitoring are compared with simulations at the residential level side by side with grab sampling of ambient measurement and evaluated as an hourly means. This study's novelty is Lagrangian mesoscale modeling to study $\mathrm{SO}_{2}$ and $\mathrm{NO}_{2}$ dispersion in typical Indonesian residential communities, which is free software, easy to operate with the large capacity of modeling computation with friendly GUI run in a familiar operating system like Windows. The main objectives were; to validate GRAL comprehensively on $\mathrm{SO}_{2}$ and $\mathrm{NO}_{2}$ dispersion in an Indonesian residential community near the coal-steam power plant, with a $6 \mathrm{~km} \mathrm{x}$ $8 \mathrm{~km}$ resolution, and evaluate three-dimensional dispersion of coal-steam power plant $\mathrm{SO}_{2}$ and $\mathrm{NO}_{2}$ in areas near to it, with 48 square kilometres domain.

\section{METHOD}

\subsection{Site description and observations}

The community in this study was a typical Indonesian residential community near the coal-steam power plant in southern Java. Based on topographical characteristics, the residential community's mean building height was 3 meters. This coal-steam power plant has two-unit processes, with has a stack height of 240 meters and 220 meters, with 6.8meters and 7.8-meters inside diameters. Based on this data, there is a possibility to simulate monthly $\mathrm{SO}_{2}$ and $\mathrm{NO}_{2}$ as dominant emissions from the coal-steam power plant. Simulation using GRAL was analyzed in quarterly periods as the ambient measurement was conducted every three months. Each parameter will be analyzed respectively. $\mathrm{NO}_{2}$ concentration will convert from $\mathrm{NO}_{\mathrm{x}}$ as empirical equation (1) (Middleton, Luhana, Sokhi, \& Great Britain. Environment Agency., 2007), where $\mathrm{NO}_{2}$ concentration would be equal as 1.58 times with $\mathrm{NO}_{\mathrm{x}}$ order to 0.6887 as constant.

$$
N O_{2}=1,58 \times N O_{x}^{0.6887}
$$

$\mathrm{SO}_{2}$ and $\mathrm{NO}_{2}$ in ambient air measured in eleven points, within hundreds of meters to several kilometers from the coal-steam power plant, $\mathrm{SO}_{2}$ measured by pararosaniline method on an hourly basis, while $\mathrm{NO}_{2}$ measured by Griesz 
Saltzman method also on one hourly. Intercomparison analysis for each receptor was evaluated using the statistical method.

\subsection{Modeling approach}

This study's GRAL model (v20.09) simulates the dispersion of multi-source gases and particulates using synoptic meteorological data. However, based on the typical topography of southern Java, where this coal-steam power plant is located, any obstacles were assumed to be ignored since there was typically flat terrain around the model domain region. Schematic for GRAL model as seen in figure 1 below.

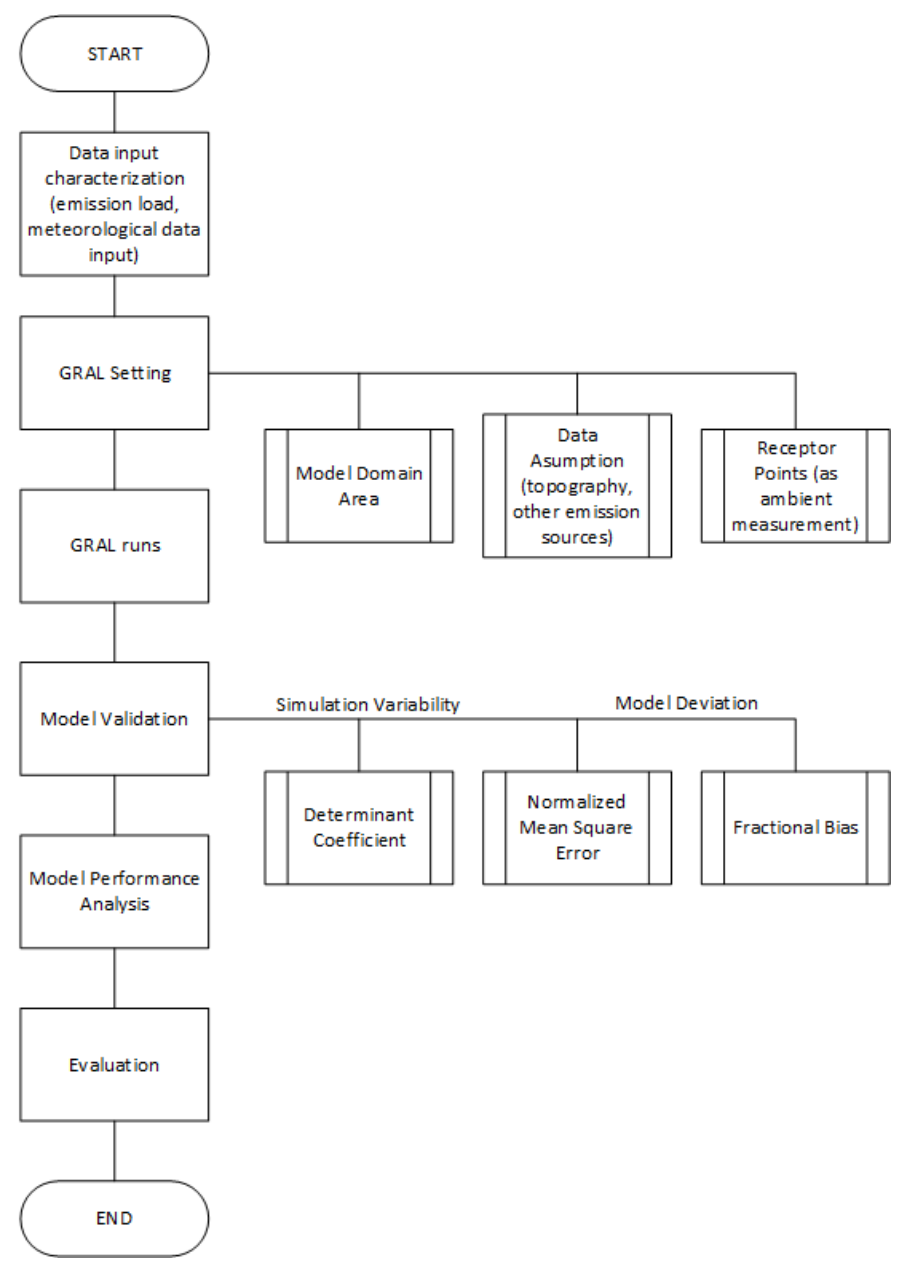

Figure 1. Schematic Run of GRAL Model

Most Gaussian dispersion models can be used for flat terrain simulation, such as CALINE 4 (Dhyani, Singh, Sharma, \& Gulia, 2013), AERMOD, ADMS (Carruthers et al., 2011), and OSPM (Hu \& Zhong, 2010). GRAL system can simulate dispersion for both flat terrain and complex terrain (Oettl, 2015). GRAL was efficient to its $\mathrm{CPU}$ time and minimum disk space computing requirements and can be used across microscales to mesoscales (Berchet et al., 2017). Meteorological wind data was collected using Copernicus ERA 5 Climate Reanalysis (Oses et al., 2020). Data was collected for the whole year in 2018 within hourly intervals, both for wind speed and wind direction meteorological data input. Data was collected through the model domain for $6 \mathrm{~km} \mathrm{x} 8 \mathrm{~km}$. As this research focused on the housing height from the ground, the vertical height was set to a minimum of 3 meters.

\subsection{Model limitation, validation, and evaluation}

The simulation result is initially outputted as the $\mathrm{SO}_{2}$ and $\mathrm{NO}_{2}$ concentration field from each emission source. At the receptor point, the total $\mathrm{SO}_{2}$ and $\mathrm{NO}_{2}$ concentration $\left(\mathrm{C}_{\text {total }}\right)$ was calculated using this equation (2);

$$
C_{\text {total }}=C_{\text {blank }}+C_{1}+C_{2}
$$

$\mathrm{C}_{\text {blank }}$ as background concentration for $\mathrm{SO}_{2}$ is 13.5 $\mu \mathrm{g} / \mathrm{Nm}^{3}$ based on (Rogers et al., 1999) and $\mathrm{NO}_{2}$ are 14.8 $\mu \mathrm{g} / \mathrm{Nm}^{3}$ based on (Jarvis, Adamkiewicz, Heroux, Rapp, \& Kelly, 2010) both are atmospheric concentration trend similar in large Indonesia cities (Susanto, 2005). $\mathrm{C}_{1}$ and $\mathrm{C}_{2}$ are the specific $\mathrm{SO}_{2}$ and $\mathrm{NO}_{2}$ increments related to each $\mathrm{SO}_{2}$ and $\mathrm{NO}_{\mathrm{x}}$ emission source. Here $\mathrm{C}_{1}$ and $\mathrm{C}_{2}$ were $\mathrm{SO}_{2}$ and $\mathrm{NO}_{\mathrm{x}}$ emissions from each coal-steam power plant stack chimney. Normalized mean square error (NMSE) and fractional bias (FB) were used to determine the optimum parameters and assess the model performance (Ling et al., 2020). This assessment can be calculated using equations (2) and (3).

$N M S E=\frac{\left(C_{o b s}-C_{S}\right)}{C_{o b s} \times C_{S}} ;($ ideal value 0, accepted value $\leq 4)$

$F B=\frac{C_{o b s}-C_{s}}{0,5 \times\left(C_{o b s}+C_{s}\right)} ;$ ideal value 0 , accepted value $-0,3 \leq \mathrm{FB}$ $\leq 0,3)$

$\mathrm{C}_{\mathrm{obs}}$ are observed $\mathrm{SO}_{2}$, and $\mathrm{NO}_{2}$ concentration and $\mathrm{C}_{\mathrm{s}}$ are simulated $\mathrm{SO}_{2}$ and $\mathrm{NO}_{2}$ concentration as hourly means, respectively. 


\section{RESULT AND DISCUSSION}

\subsection{Characteristics of the Area and Emission}

Studying the dispersion of $\mathrm{SO} 2$ and NO2 near the coal-steam power plant in southern Java can evaluate over the near region around the coal-steam power plant. This coal-steam power plant is located in coastal south Java, verge with Hindian ocean in the south. Around the coal-steam power plant, there is another coal-steam power plant $8 \mathrm{~km}$ to the east. Emission source data for this coal-steam power plant does not include in this study. There are two major emission sources at the western side of the coal-steam power plant: cement industries and oil and gas refinery plants within the $8 \mathrm{~km}$ range.

This coal-steam power plant has two chimneys; chimneys $1 \& 2$ are one chimney from two separate processes, and chimney 3 emits dominant $\mathrm{SO}_{2}$ and $\mathrm{NOx}$ to the atmosphere. Each quarter, an external laboratory conducts emission monitoring and emission load, as seen in table 1. Ministry of Environment Regulation No. 21 the year 2008 stated there is no emission load limit while emission rate should follow that regulation strictly.

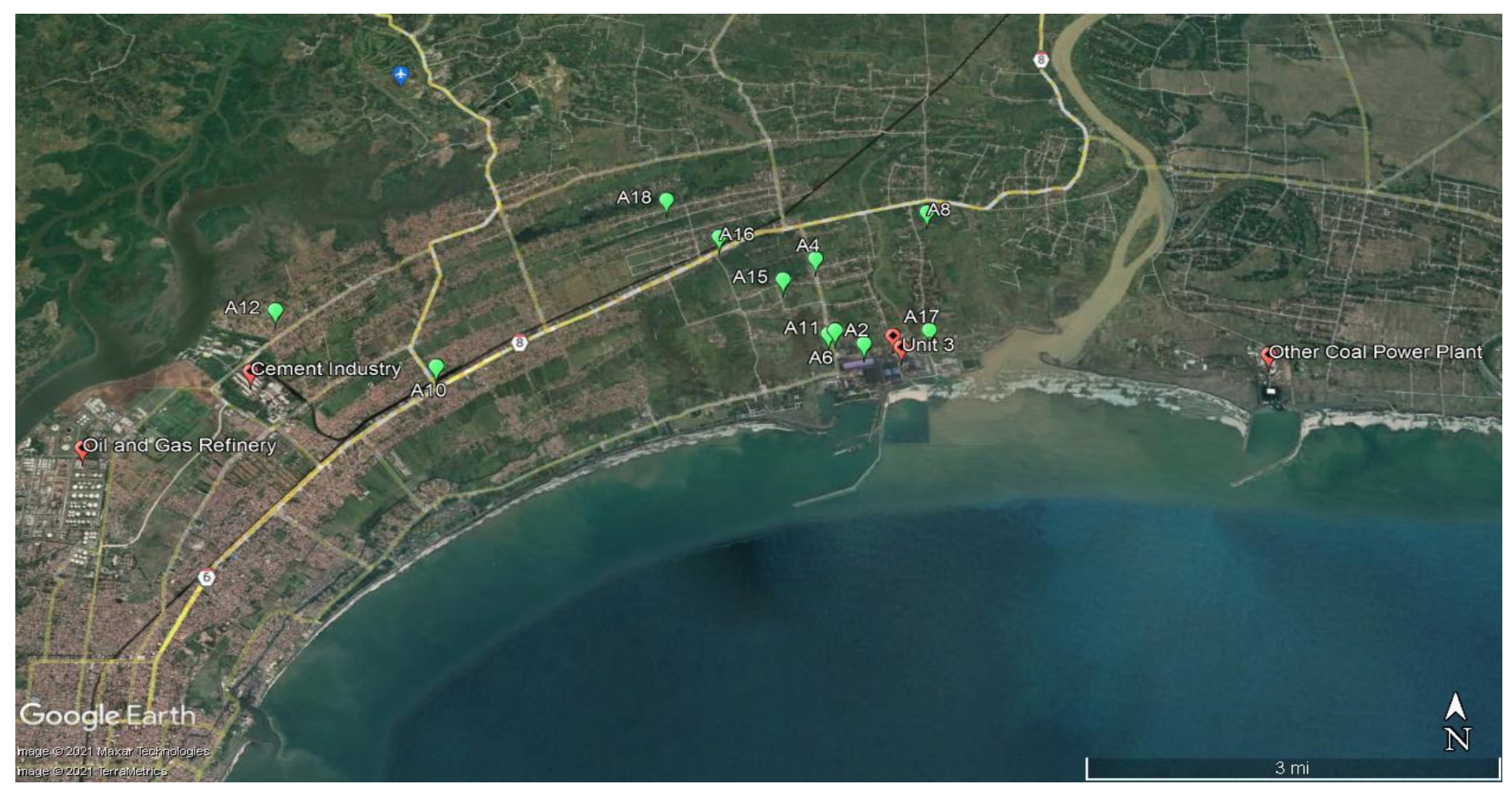

Figure 2. Geographical Characteristics Around Coal-steam Power Plant

Table 1. Emission load from coal-steam power plant
No Parameter
Chimney 182

Chimney 3

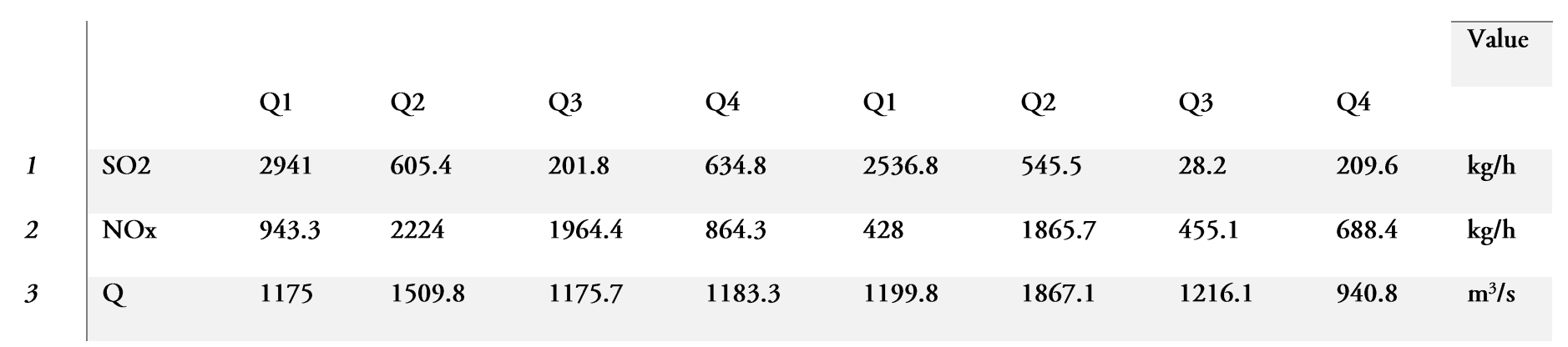




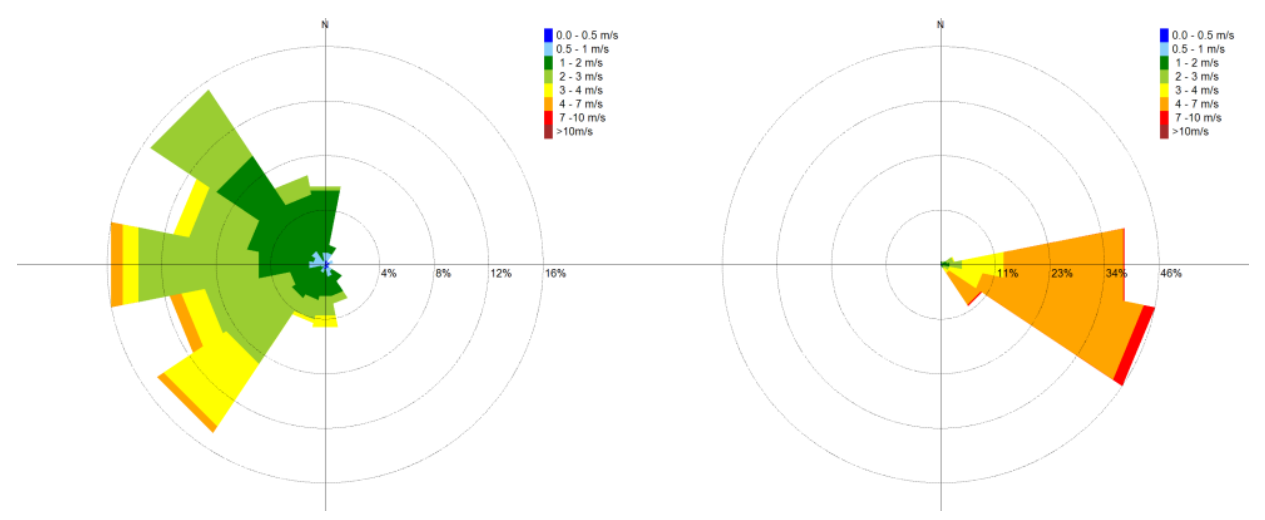

(a)

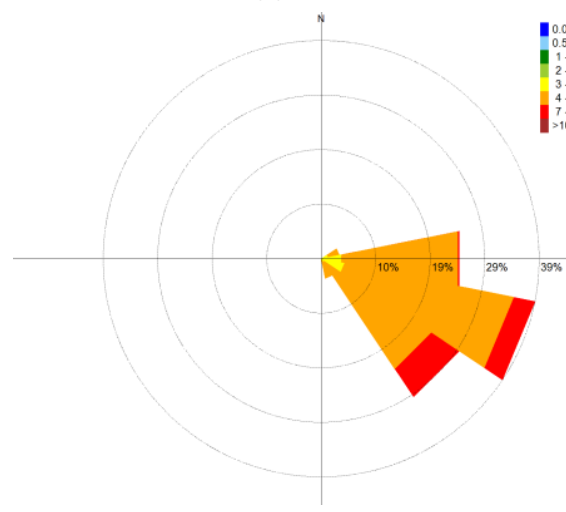

(c) (b)

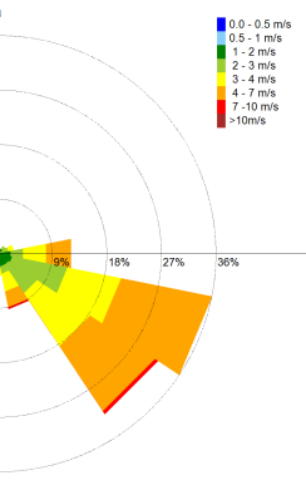

(d)

Figure 3. Spatial wind direction dominant around coal-steam power plant; (a) $1^{\text {st }}$ quarter, (b) $2^{\text {nd }}$ quarter, (c) $3^{\text {rd }}$ quarter, (d) $4^{\text {th }}$ quarter

Around the coal-steam power plant, ten receptor points are measured manually for $\mathrm{SO}_{2}$ and $\mathrm{NO}_{2}$ quarterly based on the AMDAL document, similar to emission data from the coal-steam power plant.

There were twenty-one receptors for ambient measurement around it, but only ten-point measures of $\mathrm{SO}_{2}$ and $\mathrm{NO}_{2}$, in figure 2, are signed by $\mathrm{A} 4, \mathrm{~A} 6, \mathrm{~A} 8, \mathrm{~A} 10, \mathrm{~A} 11$, A12, A15 A16, A17, and A18. Evaluating this potential dispersion pollutant possibility from the coal-steam power plant to the receptor point needs meteorological data in a quarterly period. Meteorological data from Copernicus ERA 5, wind speed, and wind direction data were collected hourly for 2018 data. Both wind speed and wind direction data around coal-steam power plant as seen in figure 3 .

Annual average of wind direction based on figure 3 wind rose originally come from South-East. The pollutant dispersion tends to disperse to the land at the Westside to the Northside of the coal-steam power plant. By quarterly analysis, only $1^{\text {st }}$ quarter tends dispersion will happen from the West side of the coal-steam power plant to the Eastside. While wind speed distribution in figure 3 indicates an average annual wind speed as high as $3-6$ meters per second. Wind speed indicates how pollutants will be diluted over the dispersion period (Kim, Lee, Woo, \& Bae, 2015). The concentration contour of $\mathrm{SO}_{2}$ and $\mathrm{NO}_{2}$ for each quarter can be seen in Figure S1-S8.

\subsection{Intercomparison Model to Observation}

$\mathrm{SO}_{2}$ and $\mathrm{NO}_{2}$ concentration from GRAL simulation for each receptor point was analyzed by intercomparison using ambient measurement in ten receptor points. This ambient data was collected by grab sampling method using the pararosaniline method for $\mathrm{SO}_{2}$, and Griesz Saltzmann method for $\mathrm{NO}_{2}$ the data compared as seen in Figure 4 and figure 5 . 


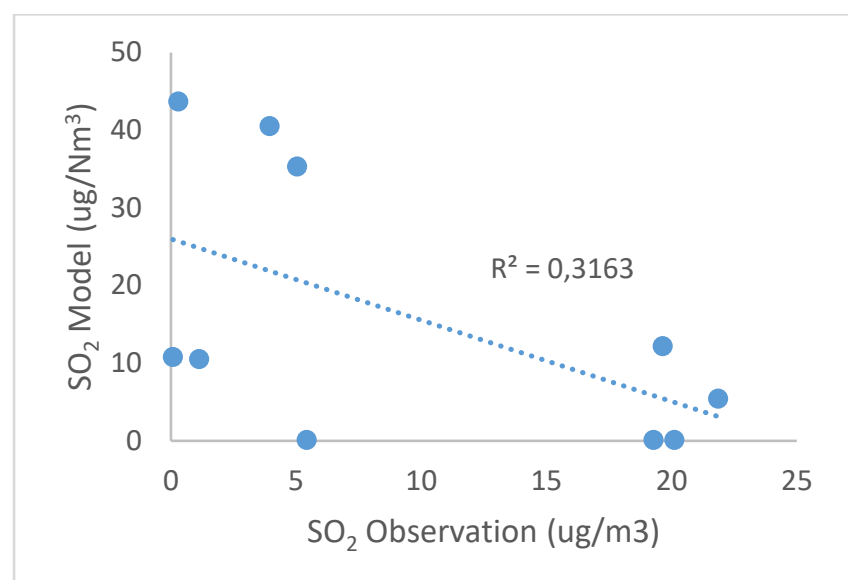

(a)

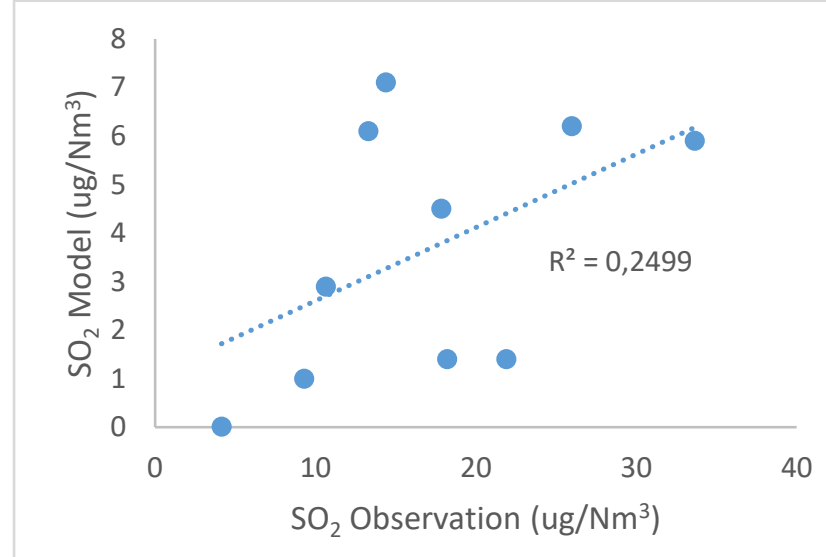

(c)

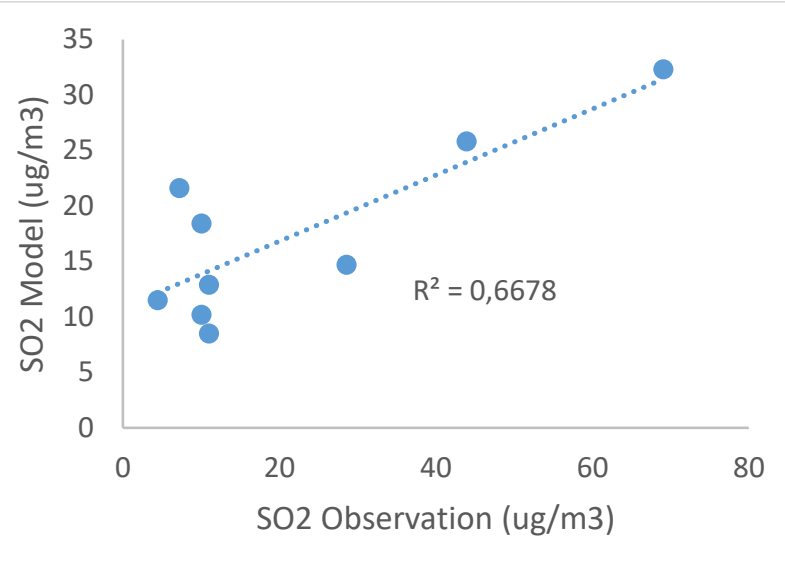

(b)

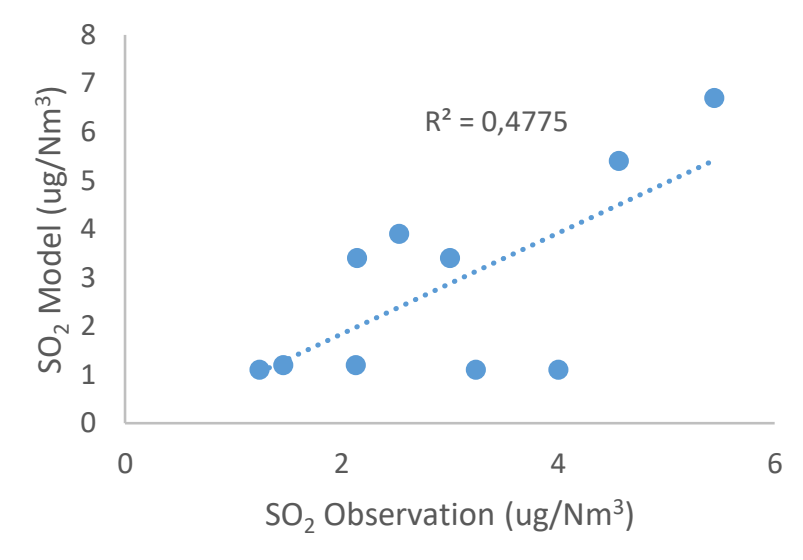

(d)

Figure 4. Scatter plot showing the relationship between $\mathrm{SO}_{2}$ observation and model; (a) $1^{\text {st }}$ quarter, (b) $2^{\text {nd }}$ quarter, (c) $3^{\text {rd }}$ quarter, (d) $4^{\text {th }}$ quarter

Observation data and modeled data relationships are shown by coefficient correlation (R). Based on simulation and observation data, there is a coefficient correlation within the range of $0.5-0.82$, which is good enough for modeled-based air pollution dispersion since it compared grab sampling and hourly modeled data. At Q1, based on the wind rose in figure 3, dominant dispersion happened from the west to the east that caused no dispersion of the pollutant from the coal-steam power plant to the receptor in the west side (A12, A10, A18, A16, A15, A6, A11, and A4). A receptor (A8) is located far to the north side to get minimum pollutant dispersion from the coalsteam power plant. This concentration is relatively equal to ambient measurement, shown below the detection limit of the pararosaniline method. In Q3 and Q4, wind direction dominantly came from the south-east and east sides; this result underestimates simulation results compared to observation data.

$\mathrm{NO}_{2}$ variability in figure 6 is shown as coefficient correlation. It has a range between $0.30-0.59$. Q3 and Q4 shown the best linear correlation between simulation and observation data. These phenomena could happen because the domestic combustion process and transportation can produce $\mathrm{NO}_{2}$. At receptor points $\mathrm{A} 6, \mathrm{~A} 6, \mathrm{~A} 8$, and 18, where measurement site near the public street, $\mathrm{NO}_{2}$ observation data shown higher than simulation data. Deviation of the simulation as model performance analysis by NMSE and FB (Chang and Hanna, 2004), NMSE, and FB value for $\mathrm{SO}_{2}$ and $\mathrm{NO}_{2}$ are seen in table 2 and table 3 . 


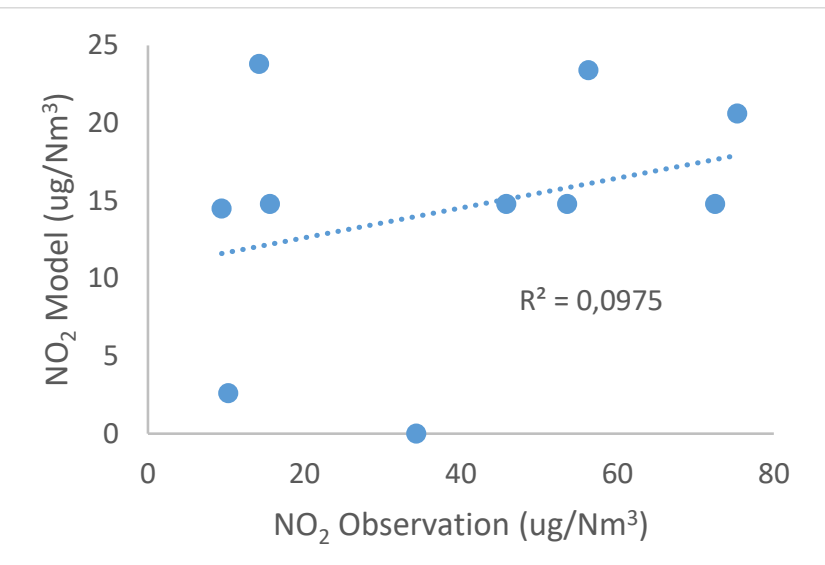

(a)

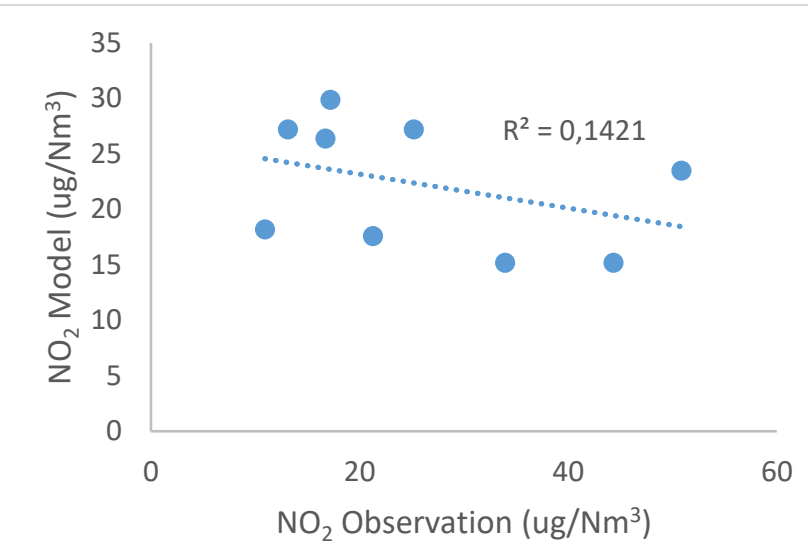

(c)

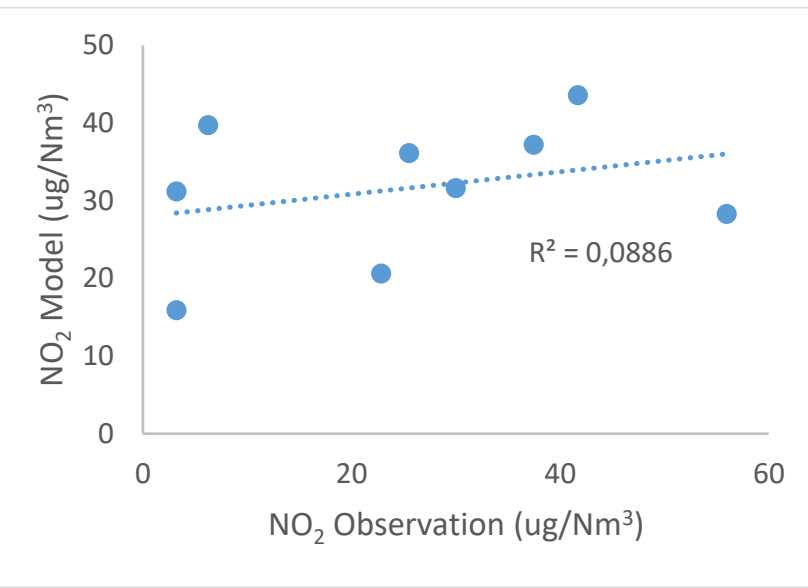

(b)

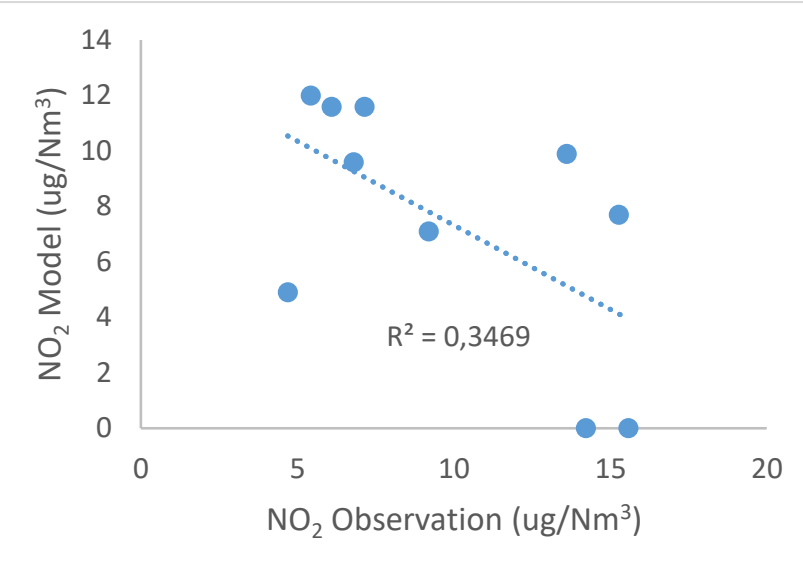

(d)

Figure 6. Scatter plot showing the relationship between $\mathrm{NO}_{2}$ observation and model; (a) $1^{\text {st }}$ quarter, (b) $2^{\text {nd }}$ quarter, (c) $3^{\text {rd }}$ quarter, (d) $4^{\text {th }}$ quarter

Table 2. NMSE and $\mathrm{FB}$ for $\mathrm{SO}_{2}$ for each location and quarter

\begin{tabular}{clcccccccc}
\hline \multirow{2}{*}{ Location } & \multicolumn{2}{c}{ Q1 } & \multicolumn{3}{c}{ Q2 } & \multicolumn{2}{c}{ Q3 } & \multicolumn{2}{c}{ Q4 } \\
\cline { 2 - 9 } & & NMSE & FB & NMSE & FB & NMSE & FB & NMSE & FB \\
\hline 1 & A4 & 0.139 & 1.208 & -0.002 & -0.020 & 0.669 & 1.760 & 0.364 & 0.559 \\
2 & A6 & 9.950 & 1.980 & 0.027 & 0.256 & 0.659 & 1.714 & 0.600 & 0.986 \\
3 & A8 & 0.031 & 0.468 & -0.013 & -0.159 & 0.166 & 1.194 & -0.173 & -0.455 \\
4 & A10 & 9.815 & 1.928 & 0.016 & 0.520 & 0.140 & 1.403 & -0.139 & -0.426 \\
5 & A11 & 9.948 & 1.979 & 0.033 & 0.641 & 0.892 & 1.612 & 0.148 & 0.195 \\
6 & A12 & -0.229 & -1.645 & 0.016 & 0.725 & 0.071 & 0.678 & -0.035 & -0.208 \\
7 & A15 & -12.728 & -1.971 & -0.139 & -0.887 & 0.251 & 1.143 & 0.103 & 0.120 \\
8 & A16 & -0.795 & -1.614 & -0.045 & -0.587 & 0.089 & 0.742 & -0.039 & -0.125 \\
9 & A17 & -3.299 & -1.973 & below detection limit & 99.758 & 1.990 & 0.659 & 1.137 \\
10 & A18 & -0.170 & -1.500 & -0.093 & -1.001 & 0.123 & 1.229 & -0.034 & -0.169 \\
& Average & 1.266 & -0.114 & -0.022 & -0.057 & $10.282^{*}$ & $1.347^{*}$ & 0.145 & 0.161 \\
\hline
\end{tabular}


Table 3. NMSE and $\mathrm{FB}$ for $\mathrm{NO}_{2}$ for each location and quarter

\begin{tabular}{llllllllllc}
\hline \multirow{2}{*}{ Location } & \multicolumn{3}{c}{ Q1 } & \multicolumn{2}{c}{ Q2 } & \multicolumn{2}{c}{ Q3 } & \multicolumn{2}{c}{ Q4 } \\
\cline { 2 - 9 } & & NMSE & FB & NMSE & FB & NMSE & FB & NMSE & FB \\
\hline 1 & A4 & 0.035 & 1.141 & 0.005 & 0.102 & 0.010 & 0.190 & 0.032 & 0.257 \\
2 & A6 & 0.054 & 1.322 & 0.017 & 0.656 & 0.043 & 0.979 & 99.930 & 1.997 \\
3 & A8 & 0.025 & 0.825 & 0.0002 & 0.007 & 0.023 & 0.736 & -0.043 & -0.342 \\
4 & A10 & 0.003 & 0.051 & -0.001 & -0.045 & -0.025 & -0.538 & -0.101 & -0.754 \\
5 & A11 & 0.046 & 1.023 & -0.250 & -1.330 & 0.036 & 0.763 & -0.009 & -0.043 \\
6 & A12 & 0.049 & 1.135 & -0.012 & -0.345 & -0.003 & -0.076 & -0.078 & -0.622 \\
7 & A15 & -0.028 & -0.504 & -0.280 & -1.628 & -0.037 & -0.499 & 0.064 & 0.659 \\
8 & A16 & 99.971 & 1.999 & -0.002 & -0.053 & -0.039 & -0.697 & 0.027 & 0.315 \\
9 & A17 & -0.037 & -0.425 & below detection limit & below detection limit & 99.936 & 1.997 \\
10 & A18 & 0.287 & 1.193 & -0.135 & -1.457 & -0.022 & -0.450 & -0.054 & -0.477 \\
& Average & $10.040^{*}$ & 0.776 & -0.073 & -0.455 & -0.001 & 0.045 & $19.970^{*}$ & 0.299 \\
\hline
\end{tabular}

*) : Unaccepted NMSE and FB range

Model performance by NMSE and FB indicate that the $\mathrm{SO} 2$ model is better than the $\mathrm{NO} 2$ model as the average range of NMSE and $\mathrm{FB}$ for $\mathrm{SO} 2$ qualified in accepted NMSE and FB interval. It can be concluded that the SO2 model is more comparable to observation data than the NO2 model (Bhat, Kumar, \& Czajkowski, 2011; El-Fadel, Abi-Esber, \& El-Fadel, 2012). The NO2 model is slightly incomparable to the observation data. It can happen due to the origin of the NO2 produced by internal combustion processes like domestic and transportation which did not include an emission source in this model. Eastern side coalsteam power industries, cement industry, and oil and gas refinery within eight kilometers range were dominant NO2 emitters which the data does not include in this study. As model input, both SO2 and NO2 were simulated using GRAL based on emission load, wind speed, and wind direction.

\section{CONCLUSION}

GRAL study as air pollution model near the coalsteam power plant showed a medium correlation between simulation and observation, with $\mathrm{SO}_{2}$ coefficient correlation (R) within $0.5-0.82$ and $\mathrm{NO}_{2}$ coefficient correlation (R) within $0.30-0.59$. Model performances analyze by NMSE and $\mathrm{FB}, \mathrm{SO}_{2}$ model seems to be more comparable to observation data since has better average NMSE and FB than $\mathrm{NO}_{2}$ model. $\mathrm{NO}_{2}$ emissions may be produced from the domestic and transportation process, and several industries within the region did not include an emission source in this study. Due to data limitation of observation collected by grab sampling instead of continuous ambient measurement system affects different response times compared with hourly data from the model. A comprehensive study needs to be conducted to alter this limitation. Serial observation ambient data is a must to analyze comparison between simulation and observation data on an hourly basis.

\section{REFERENCE}

Anfossi, D., Alessandrini, S., Trini Castelli, S., Ferrero, E., Oettl, D., \& Degrazia, G. (2006). Tracer dispersion simulation in low wind speed conditions with a new 2D Langevin equation system. Atmospheric Environment, 40(37), 7234-7245. https://doi.org/10.1016/j.atmosenv.2006.05.081

Berchet, A., Zink, K., Oettl, D., Brunner, J., Emmenegger, L., \& Brunner, D. (2017). Evaluation of high-resolution GRAMM-GRAL (v15.12/v14.8) NOx simulations over the city of Zürich, Switzerland. Geoscientific Model Development, 10(9), 3441-3459. https://doi.org/10.5194/gmd-10-3441-2017

Bhat, A., Kumar, A., \& Czajkowski, K. (2011). Development and Evaluation of a Dispersion Model to Predict Downwind Concentrations of Particulate Emissions from Land Application of Class B Biosolids in 
Unstable Conditions. In Indoor and Outdoor Air Pollution. https://doi.org/10.5772/29513

Carruthers, D. J., Seaton, M. D., McHugh, C. A., Sheng, X., Solazzo, E., \& Vanvyve, E. (2011). Comparison of the Complex Terrain Algorithms Incorporated into Two Commonly Used Local-Scale Air Pollution Dispersion Models (ADMS and AERMOD) Using a Hybrid Model. Journal of the Air \& Waste Management Association, 61(11), 1227-1235. https://doi.org/10.1080/10473289.2011.609750

Dhyani, R., Singh, A., Sharma, N., \& Gulia, S. (2013). Performance evaluation of CALINE 4 model in a hilly terrain - A case study of highway corridors in Himachal Pradesh (India). International Journal of Environment and Pollution, 52, 244-262. https://doi.org/10.1504/IJEP.2013.058455

El-Fadel, M., Abi-Esber, L., \& El-Fadel, : M. (2012). Journal of the Air \& Waste Management Association Simulating industrial emissions using Atmospheric Dispersion Modeling System: Model performance and source emission factors Simulating industrial emissions using Atmospheric Dispersion Modeling System: Model performance and source emission factors.

https://doi.org/10.1080/10473289.2011.651556

Fatkhurrahman, J. A., Sari, I. R. J., Andriani, Y., Romadhon, M. S., Zen, N., Prasetio, A., \& Simbolon, A. M. (2020). DOAS Calibration Technique for SO2 Emission Measurement Based on $\mathrm{H} 2 \mathrm{SO} 4$ and $\mathrm{Na} 2 \mathrm{SO} 3$ Reaction. Jurnal Riset Teknologi Pencegahan Pencemaran Industri, 11(1), 36-45. https://doi.org/10.21771/jrtppi.2020.v11.no1.p3645

Galán, I., Tobías, A., Banegas, J. R., \& Aránguez, E. (2003). Short-term effects of air pollution on daily asthma emergency room admissions. European Respiratory Journal, 22(5), 802-808. https://doi.org/10.1183/09031936.03.00013003

Grell, G. A., Peckham, S. E., Schmitz, R., McKeen, S. A., Frost, G., Skamarock, W. C., \& Eder, B. (2005). Fully coupled "online" chemistry within the WRF model. Atmospheric Environment, 39(37), 6957-
6975.

https://doi.org/10.1016/j.atmosenv.2005.04.027

Hu, W., \& Zhong, Q. (2010). Using the OSPM Model on Pollutant Dispersion in an Urban Street Canyon. Advances in Atmospheric Sciences, 27, 621-628. https://doi.org/10.1007/s00376-009-9064-9

Jain, R. K., Cui, Z. "Cindy," \& Domen, J. K. (2016). Environmental Impacts of Mining. In Environmental Impact of Mining and Mineral Processing (pp. 53157). Elsevier. https://doi.org/10.1016/B978-0-12804040-9.00004-8

Jarvis, D. J., Adamkiewicz, G., Heroux, M.-E., Rapp, R., \& Kelly, F. J. (2010). Nitrogen dioxide. Retrieved from https://www.ncbi.nlm.nih.gov/books/NBK138707/

Kim, K. H., Lee, S. B., Woo, D., \& Bae, G. N. (2015). Influence of wind direction and speed on the transport of particle-bound PAHs in a roadway environment. Atmospheric Pollution Research, 6(6), 1024-1034. https://doi.org/10.1016/j.apr.2015.05.007

Kurz, C., Orthofer, R., Sturm, P., Kaiser, A., Uhrner, U., Reifeltshammer, R., \& Rexeis, M. (2014). Projection of the air quality in Vienna between 2005 and 2020 for NO2 and PM10. Urban Climate, 10, 703-719. https://doi.org/10.1016/j.uclim.2014.03.008

Lin, C. K., Lin, R. T., Chen, P. C., Wang, P., De MarcellisWarin, N., Zigler, C., \& Christiani, D. C. (2018). A global perspective on sulfur oxide controls in coalfired power plants and cardiovascular disease. Scientific Reports, 8(1), 2611. https://doi.org/10.1038/s41598-018-20404-2

Ling, H., Candice Lung, S. C., \& Uhrner, U. (2020). Microscale particle simulation and traffic-related particle exposure assessment in an Asian residential community. Environmental Pollution, 266, 115046. https://doi.org/10.1016/j.envpol.2020.115046

Middleton, D. R., Luhana, L., Sokhi, R. S., \& Great Britain. Environment Agency. (2007). Review of methods for $\mathrm{NO}$ to NO2 conversion in plumes at short ranges. Retrieved from www.environment-agency.gov.uk

Mijling, B. (2020). High-resolution mapping of urban air quality with heterogeneous observations: A new methodology and its application to Amsterdam. 
Atmospheric Measurement Techniques, 13(8), 4601-4617. https://doi.org/10.5194/amt-13-46012020

Oettl, D. (2014). High resolution maps of nitrogen dioxide for the Province of Styria, Austria. International Journal of Environment and Pollution, 54(2-4), 137-146. https://doi.org/10.1504/IJEP.2014.065114

Oettl, D. (2015). Evaluation of the Revised Lagrangian Particle Model GRAL Against Wind-Tunnel and Field Observations in the Presence of Obstacles. Boundary-Layer Meteorology, 155(2), 271-287. https://doi.org/10.1007/s10546-014-9993-4

Oses, N., Azpiroz, I., Marchi, S., Guidotti, D., Quartulli, M., \& Olaizola, I. G. (2020). Analysis of copernicus' era5 climate reanalysis data as a replacement for weather station temperature measurements in machine learning models for olive phenology phase prediction. Sensors (Switzerland), 20(21), 1-22. https://doi.org/10.3390/s20216381

Quina, M., Fadhillah, F., Jiaqiao, L., \& Zhao, A. (2017). Indonesia's Coal Power Emission Norms Lessons From India And China. New Delhi. Retrieved from https://icel.or.id/wp-content/uploads/Policy-Paper-ICEL-CSE-REEI-2017-Indonesias-Coal-Power-

Emission-Norms-Lessons-from-India-China.pdf

Rogers, J. F., Killough, G. G., Thompson, S. J., Addy, C. L., Mckeown, R. E., \& Cowen, D. J. (1999). Estimating environmental exposures to sulfur dioxide from multiple industrial sources for a case-control study. Journal of Exposure Analysis and Environmental Epidemiology, 9(6), 535-545. https://doi.org/10.1038/sj.jea.7500059

Romanov, A. (2020). Graz Lagrangian Model (GRAL) for Pollutants Tracking and Estimating Sources Partial Contributions to Atmospheric Pollution in Highly Urbanized Areas. Atmosphere, 11. https://doi.org/10.3390/atmos11121375

Simbolon, A. M., Fatkhurrahman, J. A., Mariani, A., Sari, I. R. J., Syafrudin, \& Sudarno. (2021). Challenge of integrated low-cost emission monitoring system into a digital information system. In IOP Conference Series: Earth and Environmental Science (Vol. 623, p.
012076). IOP Publishing Ltd. https://doi.org/10.1088/1755-1315/623/1/012076

Susanto, J. P. (2005). Kualitas Udara Beberapa Kota Di Asia (Monitoring Kandungan SO2 Udara Ambien Dengan Passive Sampler). Jurnal Teknologi Lingkungan, $\quad 6(1)$. https://doi.org/10.29122/JTL.V6I1.332

Zhang, J. J., Wei, Y., \& Fang, Z. (2019, October 31). Ozone pollution: A major health hazard worldwide. Frontiers in Immunology. Frontiers Media S.A. https://doi.org/10.3389/fimmu.2019.02518 